\title{
MICROHABITAT SELECTION OF BROOD-REARING SITES BY GREATER SAGE-GROUSE IN CARBON COUNTY, WYOMING
}

\author{
Leslie A. Schreiber ${ }^{1,5}$, Christopher P. Hansen ${ }^{1}$, Mark A. Rumble ${ }^{2}$, Joshua J. Millspaugh ${ }^{1}$, \\ R. Scott Gamo ${ }^{3}$, Jon W. Kehmeier ${ }^{4}$, and Nate Wojcik ${ }^{4}$
}

\begin{abstract}
AвstRaCT.—Declines in Greater Sage-Grouse (Centrocercus urophasianus, hereafter sage-grouse) populations could be attributed to low chick survival, which may be influenced by the availability of food and cover at sites used by females rearing broods. Habitat attributes important to broods may vary regionally; thus, it is necessary to understand factors affecting regional sage-grouse brood-rearing site selection, especially when estimating the impacts of development. We monitored brood-rearing female sage-grouse equipped with solar Argos Global Positioning System Platform Transmitter Terminals from 2011 to 2013 to assess microhabitat selection by broods in Carbon County, Wyoming. We measured vegetation and arthropod characteristics at diurnal sites used by broods ( $n=42$ in 2011, $n=31$ in 2012, $n=$ $32 \mathrm{in} 2013)$ and at 3 paired-random sites associated with each used site $(n=315)$, located $50 \mathrm{~m}, 250 \mathrm{~m}$, and $500 \mathrm{~m}$ from the used site. We fit conditional logistic models within an information-theoretic framework to identify vegetation and arthropod characteristics associated with microsite selection of brood-rearing sites. Sage-grouse selected brood-rearing sites with greater visual obstruction (0-45.7 cm in height), higher numbers of arthropods in the order Diptera, and lower numbers of arthropods in the order Coleoptera. There was an interaction effect between the number of arthropods in the order Hymenoptera and the canopy cover of broad-leaf forbs; the relative probability of selection increased with increasing number of Hymenoptera when there was low cover $(<20 \%)$ of broad-leaf forbs, but decreased with increasing number of Hymenoptera when there was high broad-leaf forb cover $(>20 \%)$. We also found a quadratic relationship between selection of brood-rearing sites and total vegetation canopy cover; the relative probability of selection increased until approximately $75 \%$ cover and then decreased with increasing cover. Sage-grouse rearing broods selected a diverse array of vegetation types, but greatest use occurred within mesic communities. Our results could be used to identify vegetation communities with high relative probabilities of use by sage-grouse rearing broods, which will help guide management decisions and provide reference conditions for future research that evaluates the effects of wind energy development on sage-grouse.
\end{abstract}

RESUMEn.-La disminución en las poblaciones de urogallo (Centrocercus urophasianus, en adelante urogallo) podría atribuirse a la baja supervivencia de los pollos que puede estar influenciada por la disponibilidad de alimento y de refugios en los sitios donde las hembras crían a sus nidadas. Las características del hábitat que afectan a la nidada pueden variar regionalmente; por lo tanto, es necesario entender los factores que afectan la selección de las zonas de crianza del urogallo, sobre todo al estimar el impacto que tiene el desarrollo. Desde 2001 a 2013, monitoreamos la crianza de la nidada del urogallo con un Sistema de Posicionamiento Global solar (Argos Global Positioning System Platform Transmitter Terminals) para evaluar la selección de micro-hábitats para la crianza en la zona de Carbon County, Wyoming. Medimos y tomamos las características de la vegetación y de los artrópodos en sitios diurnos utilizados por las nidadas $(n=42$ en el 2011, $n=31$ en el 2012, $n=32$ en 2013) y en 3 zonas pareadas al azar asociadas a cada área utilizada $(n=$ 315), ubicadas a $50 \mathrm{~m}$, a $250 \mathrm{~m}$ y a $500 \mathrm{~m}$ de la zona utilizada. Ajustamos modelos logísticos condicionales dentro de un marco de información teórica para identificar características de la vegetación y de los artrópodos asociadas con la selección de micro-sitios para la crianza de las nidadas. El urogallo seleccionó sitios de crianza con obstrucción visual mayor, desde $0 \mathrm{~cm}$ a $45.7 \mathrm{~cm}$ de altura, con un número mayor de artrópodos del orden Diptera y con un menor número de artrópodos del orden Coleoptera. Encontramos una interacción entre el número de artrópodos del orden Himenóptera y la cobertura vegetal de herbáceas de hojas anchas; la probabilidad relativa de selección se incrementó con el aumento del número de himenópteros cuando la cobertura vegetal de herbáceas de hojas anchas fue menos densa $(<20 \%)$, pero disminuyó con el aumento del número de himenópteros cuando la cobertura de herbáceas de hojas anchas fue más densa $(>20 \%)$. Asimismo, encontramos una relación cuadrática entre la selección de áreas de crianza y la cobertura vegetal de herbáceas total. La probabilidad relativa de selección aumentó con $\sim 75 \%$ de cobertura vegetal y luego disminuyó con el incremento de la cobertura vegetal. Los urogallos seleccionaron una amplia gama de tipos de vegetación para la crianza de sus nidadas, pero utilizaron más el hábitat mésico. Nuestros resultados pueden ser utilizados para identificar las comunidades vegetales con probabilidades relativamente altas de ser utilizadas para la anidación del urogallo, lo que ayudará a guiar las decisiones de los gestores y proporcionar condiciones de referencia para futuras investigaciones que evalúen los efectos del desarrollo de energía eólica en el urogallo.

\footnotetext{
${ }^{1}$ Department of Fisheries and Wildlife Sciences, 302 ABNR Building University of Missouri, Columbia, MO 65211.

${ }^{2}$ U.S. Forest Service, Rocky Mountain Research Station, 8221 South Highway 16, Rapid City, SD 57702.

${ }^{3}$ Wyoming Game and Fish Department, 5400 Bishop Avenue, Cheyenne, WY 82006.

${ }^{4}$ SWCA Environmental Consultants, 295 Interlocken Blvd. Suite 300, Broomfield, CO 80021

5Corresponding author. E-mail: millspaughj@missouri.edı
} 
Greater Sage-Grouse (Centrocercus urophasianus; hereafter, sage-grouse) populations throughout North America have declined over the past 50 years (Garton et al. 2011) due to degradation of sagebrush (Artemisia spp.) habitats on which they depend (Braun 1998, Connelly et al. 2004, Schroeder et al. 2004), resulting in a "warranted but precluded" decision for listing under the Endangered Species Act (United States Fish and Wildlife Service 2010). Although adult female survival is paramount, chick survival also plays an important role in the population growth rate for sagegrouse (Dahlgren 2009, Taylor et al. 2012). Low chick survival is a potential factor in rangewide declines (Connelly and Braun 1997) and may be influenced by food and cover characteristics at diurnal foraging sites (Aldridge 2000, Gregg 2006, Thompson et al. 2006, Dahlgren 2009).

There is an important trade-off between nutrient/energy intake and predation risk (Lima 1998), which affects resource selection and ultimately demographic parameters. Highprotein arthropods are a critical food source for precocial tetraonid chicks for the first several weeks post-hatch (Hill 1985, Johnson and Boyce 1990, Drut et al. 1994, Jamison et al. 2002, Hannon and Martin 2006), and forbs are important food sources for sage-grouse chicks later in the summer (Klebenow and Gray 1968, Klebenow 1969, Drut et al. 1994). Further, the horizontal and vertical protective cover that vegetation provides may be crucial to prevent predation and exposure-related chick mortality (Klebenow 1969, Wallestad 1971, Klott and Lindzey 1990, Sveum et al. 1998). Limited available habitat that offers adequate food and cover resources, especially during dry years, could result in low recruitment (Aldridge 2000).

Sage-grouse rearing broods generally select sites with less sagebrush cover, taller grasses, and more forbs (Hagen et al. 2007), but there are regional differences. Kirol et al. (2012) found that sagebrush cover and grass structure were more important to brood-rearing sagegrouse than forbs in xeric sagebrush communities (Kirol et al. 2012). Similarly, forbs were not as important to brood-rearing site selection as sagebrush in Alberta (Aldridge and Brigham 2002). Thus, it is necessary to understand factors affecting regional sage-grouse brood-rearing site selection, especially when evaluating the possible impacts of development. Our research was part of a Before-After, Control-Impact study collecting $>3$ years of data on sage-grouse prior to construction of a wind energy facility that will consist of 1000 turbines and produce 2000-3000 megawatts of energy (Power Company of Wyoming LLC 2009). Our objectives were to determine the food and cover resources associated with selection of microsites by female sage-grouse rearing broods, and estimate how varying resource characteristics (e.g., increasing forb cover) might affect relative probability of selection. Results from this study will provide insight on management of brood-rearing habitat and act as baseline data for future studies estimating the potential effects of wind energy development on sage-grouse selection of broodrearing sites.

\section{Methods \\ Study Area}

Our study area was located in Carbon County, Wyoming, USA, and encompassed the approximately 1295-km² Overland Trail Ranch and surrounding areas (Fig. 1). The area was characterized by a checkerboard private/public ownership pattern with approximately half of the land administered by the Bureau of Land Management and a small portion owned by the state of Wyoming.

Annual precipitation over the past 60 years averaged $22.8 \mathrm{~cm}$ in Rawlins, Wyoming, and $24.6 \mathrm{~cm}$ in Saratoga, Wyoming (Western Regional Climate Center 2013). Precipitation increased with elevation, which ranged from about $1890 \mathrm{~m}$ at the North Platte River to $2590 \mathrm{~m}$ near the Continental Divide. The study area was characterized topographically by a central basin that transitioned to foothills to the south, mesas to the southwest, and rocky escarpments to the north and northeast (Love and Christiansen 1985). The average monthly temperature was $0.7-12.7{ }^{\circ} \mathrm{C}$ from November to April and $15.3-28.5^{\circ} \mathrm{C}$ from May to October (Western Regional Climate Center 2013).

The study area consisted of 3 ecoregions, including rolling sagebrush steppe, salt desert shrub basins, and foothill shrublands (Chapman et al. 2004). Rolling sagebrush steppe comprised approximately $66 \%$ of the study area and was characterized by Wyoming big 


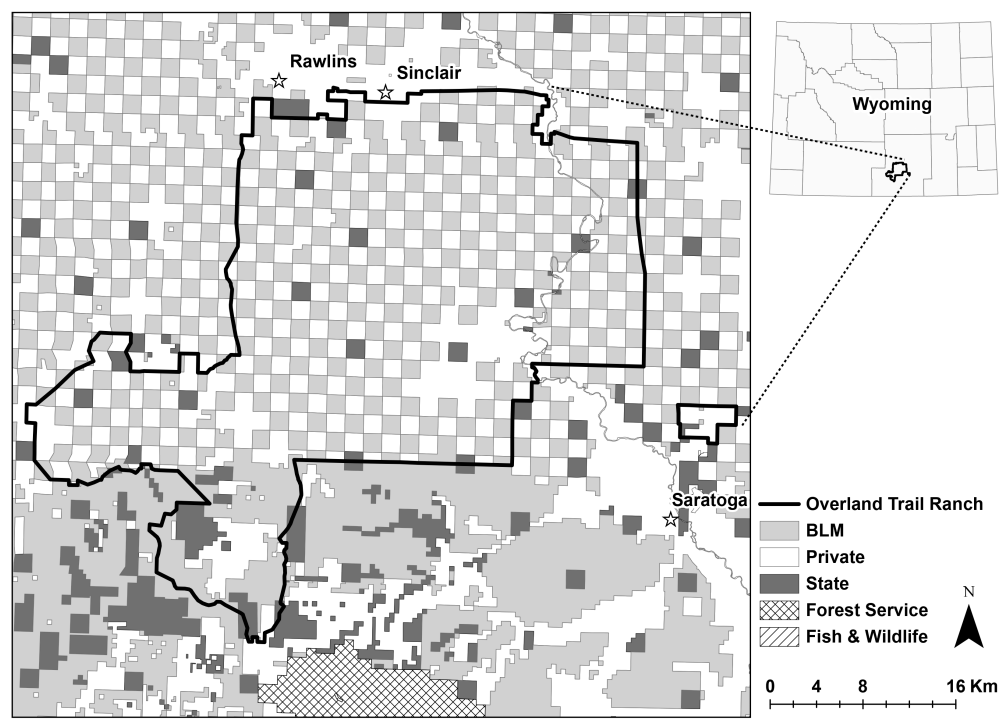

Fig. 1. Map showing the surface ownership on and near the Overland Trail Ranch, in Carbon County, Wyoming, USA, where we studied Greater Sage-Grouse selection of brood-rearing microsites from 2011 to 2013.

sagebrush (Artemisia tridentata wyomingensis) at lower elevations, continuous stands of mountain big sagebrush (A. t. vaseyana) at higher elevations, silver sagebrush (Artemisia cana) in areas where the water table was within $1 \mathrm{~m}$ of the soil surface (Thatcher 1959), and black sagebrush (Artemisia nova) in exposed, rocky soils (Chapman et al. 2004). Other shrubs included rabbitbrush (Chrysothamnus spp. and Ericameria nauseosa); common forbs included phlox (Phlox spp.), mock goldenweed (Stenotus spp.), clover (Trifolium spp.), madwort (Alyssum spp.), and vetch (Astragalus spp.); common grasses included western wheatgrass (Pascopyrum smithii), bluebunch wheatgrass (Pseudoroegneria spicata), needleand-thread (Hesperostipa comata), Idaho fescue (Festuca idahoensis), Sandberg bluegrass (Poa secunda), and prairie junegrass (Koeleria macrantha).

Salt desert shrub, which comprised approximately $19 \%$ of the study area, was characterized by sparse vegetation cover of Gardner's saltbush (Atriplex gardneri), shadscale (Atriplex confertifolia), and black greasewood (Sarcobatus vermiculatus). Sagebrush cover in this ecoregion, predominantly Wyoming big sagebrush and basin big sagebrush (A. t. tridentata), was sporadic and isolated to areas with topographic relief and sustained soil moisture. Forbs were scarce and usually comprised of mock goldenweed and cushion-like phlox. Grass species included alkali cordgrass (Spartina gracilis), Indian ricegrass (Oryzopsis hymenoides), blowout grass (Redfieldia flexuosa), alkali wildrye (Leymus simplex), and needleand-thread (Chapman et al. 2004).

Montane deciduous shrublands, which comprised approximately 15\% of the study area, were located at higher elevations and characterized by mountain big sagebrush, snowberry (Symphoricarpos spp.), serviceberry (Amelanchier spp.), mountain mahogany (Cercocarpus spp.), groves of aspen (Populus tremuloides), and patches of limber pine (Pinus flexilis). A variety of forbs and grasses were also abundant including vetch, clover, lupine (Lupinus spp.), prairie junegrass, bluebunch wheatgrass, and western wheatgrass (Chapman et al. 2004).

\section{Field Methods}

In spring 2010-2013, we used spotlighting techniques to capture female sage-grouse (Giesen et al. 1982). Each was fitted with a 30-g rump-mounted (Rappole and Tipton 1991) solar Argos Global Positioning System Platform Transmitter Terminal (GPS PTT; Microwave Telemetry, Inc., Columbia, MD). Capture and handling protocols were approved by the University of Missouri Animal Care and Use Committee, permit number 6750, 
and Wyoming Game and Fish Department Chapter 33 Permit, permit number 752 .

GPS PTTs recorded 6-8 locations per day during the brood-rearing season and we downloaded location data from Argos satellites every 3-5 days. GPS PTTs also transmitted ultra high frequency signals for approximately $8 \mathrm{~h}$ per day to facilitate ground-tracking. We investigated potential nest sites when we witnessed multiple locations of a female $<50 \mathrm{~m}$ apart over a 48-h period; nests were visually confirmed from a distance $>10 \mathrm{~m}$ to avoid disturbing the female. We utilized GPS location data to determine dates of nest abandonment (success or failure), evidenced by $>3$ diurnal GPS locations $>50 \mathrm{~m}$ from the nest. When the female ceased incubating, we investigated the nest bowl to determine the fate of the nest. If the hen incubated $>25$ days and at least 1 eggshell had a detached membrane (Girard 1939), signifying a hatched egg, we assumed the nest was successful. After a nest successfully hatched, we verified that the female had chicks by spotlighting the brood (Dahlgren et al. 2010) $\leq 4$ days before selecting a site for measurements. We characterized the vegetation and arthropod community at GPS locations of the female rearing a brood to assess selection of brood-rearing sites. For each brooding female, we selected and measured resources at $\geq 1$ location during the first $7 \mathrm{~d}$ post-hatch, $\geq 1$ location during 8-14 d posthatch, and $\geq 1$ location approximately every 14 $\mathrm{d}$ until the chicks were absent or reached $70 \mathrm{~d}$ of age, representing independence (e.g., Beck et al. 2006, Thompson 2012). All locations selected for measurements were diurnal locations from the previous 4 days.

We measured vegetation characteristics and arthropod abundance at used sites and 3 paired-random sites located $50 \mathrm{~m}, 250 \mathrm{~m}$, and $500 \mathrm{~m}$ from the used site to quantify resource availability at different scales (e.g., Swanson et al. 2013). At each used and paired-random site, we measured vegetation characteristics along 20-m transects radiating in each cardinal direction. We completed our field measurements at the paired-random sites within 2 days of measuring the used site to ensure comparable conditions. We recorded all vegetation data on Allegro CX and MX data loggers (Juniper Systems, Logan, UT).

We measured the height of visual obstruction using a modified Robel pole (Robel et al.
1970, Benkobi et al. 2000) as a cover board at 5 -m increments along each transect, $(n=20$ measurements/site). The modified Robel pole consisted of seventy-two $1.27-\mathrm{cm}$ segments divided into four 18-segment sections. At a distance of $4 \mathrm{~m}$ from the pole and at a height of $1 \mathrm{~m}$, we recorded the number of segments with $>50 \%$ obstruction in each section and averaged values to estimate visual obstruction. We used the point-centered quarter method (Cottam and Curtis 1956) to estimate density of all sagebrush and sagebrush $>20 \mathrm{~cm}$ in height, excluding birdfoot sagebrush (Artemisia pedatifida) and fringed sagebrush (Artemisia frigida). We measured the distance to the nearest sagebrush in each of 4 quadrants surrounding the plot center, the $10-\mathrm{m}$ increment, and the 20-m increment along each transect ( $n=36$ measurements per site). Equations in Pollard (1971) were used to estimate sagebrush density at each site.

While the line intercept method is more commonly used to estimate shrub cover (e.g., Connelly et al. 2003), quadrat methods (Daubenmire 1959) are more efficient, produce similar estimates to the line intercept method (Hanley 1978), and accurately estimate canopy cover (Booth et al. 2006). Thus, we estimated foliar canopy cover using a $0.1-\mathrm{m}^{2}$ quadrat (Daubenmire 1959) at 2.5-m increments out to $20 \mathrm{~m}$ along each transect $(n=36$ measurements per site). We estimated foliar canopy cover of sagebrush, non-sagebrush shrubs, forbs, grasses, and all vegetation combined, excluding litter (total vegetation cover). We further divided forbs and grasses into broadleaf forbs, cushion forbs, bunchgrasses, and rhizomatous grasses to separate growth forms (e.g., Cagney et al. 2010). Broad-leaf forbs generally grew in a vertical pattern with broad leaves (e.g., lupine, clover, dandelion [Taraxacum spp.]); cushion forbs grew in a matforming pattern (e.g., phlox, goldenweed, pussytoes [Antennaria spp.]); bunchgrasses grew in a "clumped" pattern (e.g., bluebunch wheatgrass, prairie junegrass); and rhizomatous grasses grew from rhizomes (e.g., western wheatgrass, Kentucky bluegrass [Poa pratensis]). We measured all vegetation types within the quadrat, even if they were covered by other species. We categorized vegetation using 6 cover classes (Daubenmire 1959): 0 (no cover), 1 (trace-5\% cover), 2 (5.1\%-25\% cover), 3 (25.1\%-50\% cover), 4 (50.1\%-75\% 
cover), 5 (75.1\%-95\% cover), and 6 (95.1\%$100 \%$ cover). We recoded cover classes to the midpoints (e.g., $1=2.5 \%, 2=15 \%$, etc.) and averaged values to obtain estimates of foliar canopy cover for vegetation. We also measured the height of the sagebrush, nonsagebrush shrub, forb, and grass (natural droop height) nearest to the corner of the quadrat that touched the transect increment and then averaged values to estimate vegetation height.

We collected arthropods within $1-\mathrm{m}^{2}$ quadrats covered with $0.635-\mathrm{mm}$ mesh netting using a gasoline-powered backpack aspirator with a collection bag (model 1612; John W. Hock Company, Gainesville, FL). We placed quadrats $10 \mathrm{~m}$ and $20 \mathrm{~m}$ from the plot center along transects projected $45^{\circ}$ and $225^{\circ}$, and 20 $\mathrm{m}$ from the plot center along transects projected $135^{\circ}$ and $315^{\circ}(n=6)$. We vacuumed soil and vegetation surfaces within the net for $2 \mathrm{~min}$, putting equal effort into collecting ground-dwelling, vegetation-dwelling, and flying arthropods. We transferred the collected material to a labeled, resealable bag and placed the contents in a freezer. We separated all identifiable arthropods and parts from debris, then oven-dried arthropods at $55{ }^{\circ} \mathrm{C}$ for $24 \mathrm{~h}$. We sorted arthropods to order, then counted and weighed samples to the nearest milligram. After the 2012 field season, we eliminated arthropod collection from our sampling protocol because collection and sorting was not within the budget.

\section{Analytical Methods}

We analyzed sage-grouse selection of brood-rearing sites in 2011-2012 and 20112013 separately because we did not collect arthropods in 2013. We used a multistage (e.g., Franklin et al. 2000) information-theoretic modeling approach (Burnham and Anderson 2002) to evaluate the relative importance of arthropod and vegetation characteristics on selection of brood-rearing sites. Sage-grouse rearing broods might select different site attributes during early (chicks $<3$ weeks old; Connelly et al. 2000) and late (chicks >3 weeks old) brood-rearing periods (e.g., Connelly et al. 2011). Thus, before modeling procedures, we performed multiresponse permutation procedure (MRPP) analyses on arthropod and vegetation characteristics at used sites to determine whether early and late brood-rearing periods should be separated for model analysis.

Next, we developed models of factors affecting selection of brood-rearing sites and grouped these models into food and cover hypothesis sets. Coleoptera (beetles) and Hymenoptera (ants) are the arthropod orders most widely consumed by sage-grouse chicks (Klebenow and Gray 1968, Peterson 1970, Drut et al. 1994), so we included these arthropod orders in food models. Diptera (flies) were abundant on our field site and are also consumed by chicks (Klebenow and Gray 1968), so we included Diptera in food models as well. Orthoptera (grasshoppers) and Lepidoptera (caterpillars/butterflies) may also be important arthropods in sage-grouse chick diets (Peterson 1970, Gregg and Crawford 2009), but they were not abundant on our field site, so we excluded them from food models. Chicks also consume many species of broadleaf forbs, (Klebenow and Gray 1968, Peterson 1970, Drut et al. 1994) and some cushion forbs (e.g., phlox; Klebenow and Gray 1968), especially late in the brood-rearing season, so we included these forb groups in food models as well.

The horizontal and vertical protective cover that vegetation provides may be crucial to prevent predation and exposure-related chick mortality (Wallestad 1971, Sveum et al. 1998, Aldridge and Brigham 2002, Thompson et al. 2006, Kaczor et al. 2011, Kirol et al. 2012). This cover is often provided by sagebrush and grasses (e.g., Aldridge and Brigham 2002, Thompson et al. 2006, Hagen et al. 2007, Kirol et al. 2012), so we included sagebrush, grass, and total vegetation cover and height variables in cover models. Vegetation provides visual obstruction which may be positively correlated with brood-rearing site selection (Kaczor et al. 2011); therefore, we also included this variable in cover models. Finally, cheatgrass (Bromus tectorum) may have a negative association with selection (Kirol et al. 2012), so we incorporated this variable in cover models with the hypothesis that sage-grouse would avoid sites with cheatgrass.

We determined which form of each continuous variable, including linear, quadratic, and pseudothreshold (e.g., Franklin et al. 2000), was most supported by comparing values of Akaike's information criterion (Akaike 1973) 
adjusted for small sample size $\left(\mathrm{AIC}_{c}\right)$ across variable forms. We used the nonlinear form of the variable if it was $>2 \mathrm{AIC}_{c}$ units better than the linear form; otherwise, we used the linear form. Similarly, we evaluated interactions between variables if there was sound reasoning for the interaction. We maintained the interaction term through the modeling process if the model was $>2 \mathrm{AIC}_{c}$ units better than an equivalent model without an interaction. We checked for multicollinearity between variables by calculating Pearson's correlation coefficient $(r)$ using PROC CORR (SAS 9.3, SAS Institute, Inc., Cary, NC). If $r>0.65$, we removed the correlated variable with the highest $\mathrm{AIC}_{c}$ value.

Finally, we ranked models within food and cover hypothesis sets and combined models with $\mathrm{AIC}_{c}$ values $<2$ from each set to evaluate which hypothesis, or combination of hypotheses, explained the most variation in resource selection by females rearing broods. We did not include arthropod variables in 2011-2013 models, so we did not separate food and cover hypotheses for 2011-2013 model analyses. If we noticed relationships consistent with prior knowledge of sage-grouse biology that we had not previously considered, we created post hoc models to compare against other models in the set. If model uncertainty existed in our final model set, we averaged models within $2 \mathrm{AIC}_{c}$ units of the top model (Burnham and Anderson 2002).

We used conditional logistic regression to calculate model parameter estimates and relative selection probabilities because we assumed the probability of selecting a site was relative to other available sites unique to that individual. We fit conditional logistic models using PROC PHREG (SAS Institute, Inc., Cary, NC) and included a gamma-distributed random effect for each individual grouse to account for association among multiple sites selected by one individual along with any unobserved heterogeneity. The same random effect was used across all candidate models because our focus was to determine the best predictive model based on population-level inferences of brood-rearing site selection, instead of a focus on individual grouse. For that reason, we based model selection on the marginal AIC (Vaida and Blanchard 2005) corrected for the number of fixed-effect parameters specified in the model.
We evaluated model performance by calculating McFadden's pseudo $R^{2}\left(\rho^{2}\right)$, which can be interpreted as the proportion of the total variability explained by the model (McFadden 1974). We considered $\rho^{2}$ values $>0.2$ to represent excellent model fit (McFadden 1978). We also estimated squared semipartial correlations to determine how much each variable in the final model contributed to the explained variation (Cohen and Cohen 1975). We calculated $\rho^{2}$ for the most supported model, then calculated $\rho^{2}$ for a reduced model. The difference between $\rho^{2}$ of the full and reduced models represented the squared semipartial correlation of the variable excluded. We repeated this procedure for each variable included in the most supported model and assumed the variable with the smallest squared semipartial correlation contributed the least to the explained variation in selection of brood-rearing sites.

We evaluated the predictive ability of our top models by using a modified $k$-fold crossvalidation, "leave one out" design (Boyce et al. 2002, Leblond et al. 2010). We successively removed 1 choice set $(1$ used and 3 pairedrandom sites; "test" data) from the data and refit the most-supported model using the remaining data ("training" data). We calculated relative selection probabilities for each site in the "test" choice set using the new parameter estimates derived from the training data and ranked sites based on relative probability of selection. We assessed model performance by examining the proportion of choice sets where the site selected by the brood-rearing female had the highest relative probability of selection, compared to the paired-random sites. Given that the choice set consisted of 4 options, we expected a predictive success of $25 \%$ due to random chance alone. To understand how well our model predicted relative selection at different scales, we also calculated the proportion of choice sets where the used site had a higher relative probability of selection compared to the individual random sites located $50 \mathrm{~m}$, $250 \mathrm{~m}$, and $500 \mathrm{~m}$ from the used site. For these comparisons, we expected a predictive success of $50 \%$ due to random chance. We expected a good predictive model to show a large proportion of used sites with higher relative probabilities of selection than random sites. 


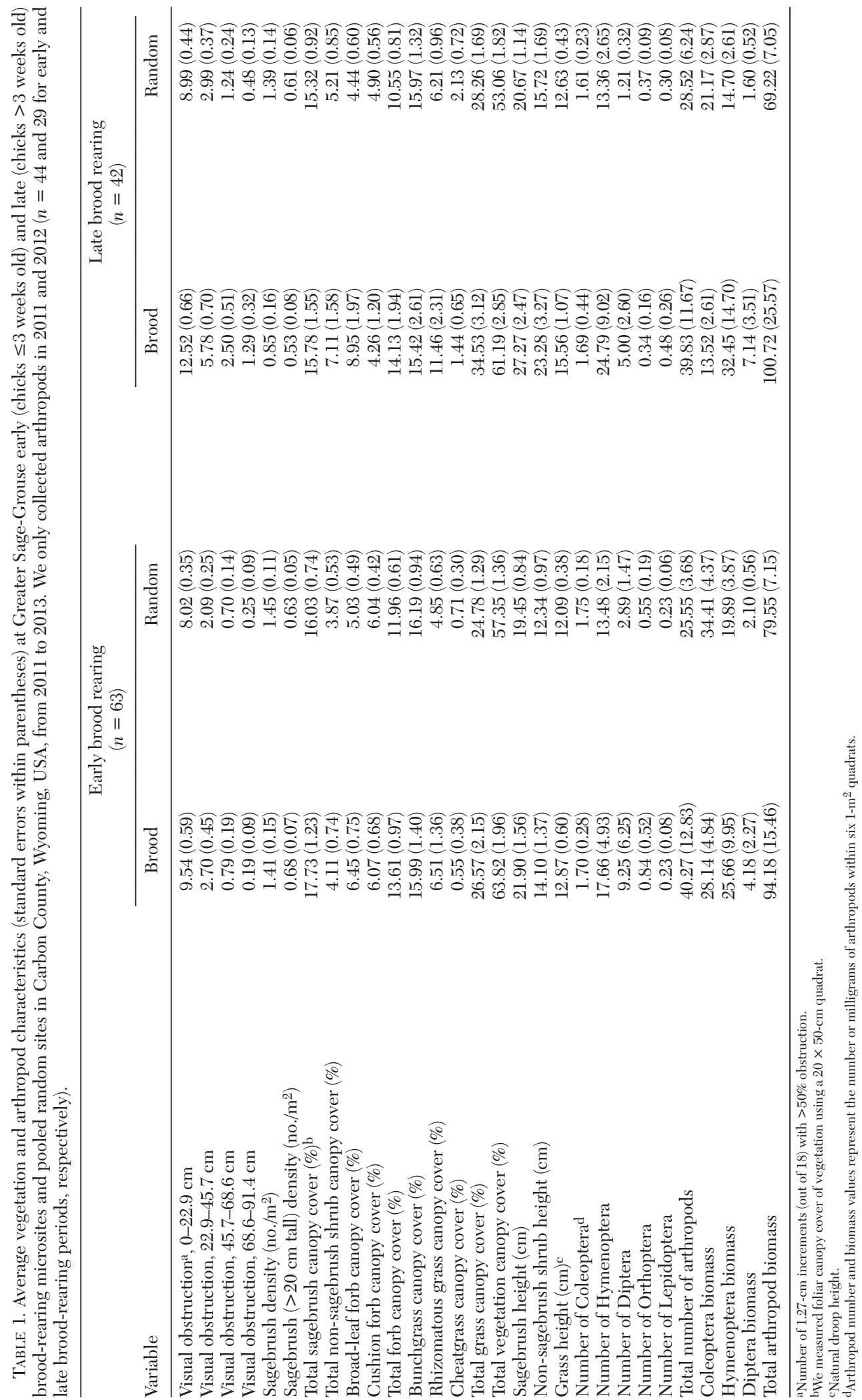


TABLE 2. Model structure, number of parameters (K), log likelihood (LL), Akaike's information criterion for small sample sizes $\left(\mathrm{AIC}_{c}\right)$, difference in $\mathrm{AIC}_{c}\left(\Delta \mathrm{AIC}_{c}\right)$, Akaike weight $\left(w_{i}\right)$, and $\mathrm{McFadden}$ 's pseudo $\mathrm{R}^{2}\left(\rho^{2}\right)$ for food hypotheses explaining Greater Sage-Grouse selection of brood-rearing microsites in Carbon County, Wyoming, USA, from 2011 to 2013. We excluded arthropod variables from model analysis because arthropods were not sampled in 2013.

\begin{tabular}{|c|c|c|c|c|c|c|}
\hline Model $^{\mathrm{a}}$ & $\mathrm{K}$ & LL & $\mathrm{AIC}_{c}$ & $\Delta \mathrm{AIC}_{c}$ & $w_{i}$ & $\rho^{2}$ \\
\hline $\begin{array}{l}\text { PT b_Hym + PT_Dip + Col + } \\
\text { PT_BroadForb }+ \text { PT_Hym*PT_BroadForb }\end{array}$ & 6 & -159.997 & 332.291 & 0.000 & 0.525 & 0.080 \\
\hline $\begin{array}{l}\text { PT_Hym + PT_Dip + PT_BroadForb + } \\
\text { PT_Hym*PT_BroadForb }\end{array}$ & 5 & -162.078 & 334.367 & 2.077 & 0.186 & 0.068 \\
\hline Global & 8 & -159.830 & 336.171 & 3.880 & 0.076 & 0.081 \\
\hline $\begin{array}{l}\text { PT_Hym + Col + PT_BroadForb + } \\
\text { PT_Hym*PT_Broad̄Forb }\end{array}$ & 5 & -163.215 & 336.640 & 4.349 & 0.060 & 0.062 \\
\hline $\begin{array}{l}\text { PT_Hym + PT_BroadForb + } \\
\text { PT_Hym*PT_BroadForb }\end{array}$ & 4 & -164.408 & 336.955 & 4.665 & 0.051 & 0.055 \\
\hline PT_Dip + Col + PT_BroadForb & 4 & -164.851 & 337.842 & 5.551 & 0.033 & 0.052 \\
\hline $\begin{array}{l}\text { PT_TotArt + PT_BroadForb + } \\
\text { PT_TotArt*PT_BroadForb }\end{array}$ & 4 & -165.216 & 338.571 & 6.281 & 0.023 & 0.050 \\
\hline PT_Dip + PT_BroadForb & 3 & -166.508 & 339.100 & 6.809 & 0.017 & 0.043 \\
\hline $\begin{array}{l}\text { PT_Dip + Cō̄ + PT_BroadForb }+ \\
\text { PT_CushionForb }\end{array}$ & 5 & -164.808 & 339.826 & 7.535 & 0.012 & 0.052 \\
\hline PT_BroadForb & 2 & -168.435 & 340.911 & 8.620 & 0.007 & 0.032 \\
\hline Col̄ + PT_BroadForb & 3 & -167.671 & 341.426 & 9.135 & 0.005 & 0.036 \\
\hline PT_BroadForb + PT_CushionForb & 3 & -168.409 & 342.902 & 10.611 & 0.003 & 0.032 \\
\hline PT_TotArt + PT_CushionForb & 3 & -168.721 & 343.526 & 11.235 & 0.002 & 0.030 \\
\hline TotForb & 2 & -172.893 & 349.828 & 17.537 & 0.000 & 0.006 \\
\hline Null & 1 & -173.915 & 349.845 & 17.554 & 0.000 & 0.000 \\
\hline PT_CushionForb & 2 & -172.978 & 349.998 & 17.707 & 0.000 & 0.005 \\
\hline Cō̄ + PT_CushionForb & 3 & -172.959 & 352.002 & 19.711 & 0.000 & 0.005 \\
\hline
\end{tabular}

a Hym = number of Hymenoptera; Dip = number of Diptera; Col = number of Coleoptera; TotArt = total number of arthropods; BroadForb = foliar canopy cover of broad-leaf forbs; CushionForb = foliar canopy cover of cushion/mat-forming forbs; TotForb = foliar canopy cover of all forbs; Global = fully parameterized model; Null = unparameterized model.

bPT: Pseudothreshold form of the variable.

\section{RESULTS}

We monitored 48 female sage-grouse $(n=$ 15 yearlings) during the nesting season (15 April-15 June) in 2011, 51 females $(n=2$ yearlings) in 2012 , and 47 females ( $n=1$ yearling) in 2013. We verified 49 nests (19 successful) in 2011, 41 nests (14 successful) in 2012, and 39 nests (9 successful) in 2013. We monitored 14 broods in 2011, 14 broods in 2012, and 9 broods in 2013. We measured 105 sites $(n=42$ in 2011, $n=31$ in 2012, $n=32$ in 2013) used by broods and 315 paired-random sites ( $n=105$ sites at each distance) to evaluate selection of brood-rearing sites (Table 1). We measured an average of 3-4 brood-rearing sites per female each year.

Only 5 of 25 variables we included in MRPP analyses showed significant differences between early and late brood-rearing periods. These included visual obstruction from $0 \mathrm{~cm}$ to $45.7 \mathrm{~cm}$ in height, density of sagebrush, foliar canopy cover of cushion forbs and grasses, and grass height. Thus, we grouped early and late brood-rearing periods for model analysis.

We evaluated 17 food models and 15 cover models with the 2011-2012 data set. The most supported food model included number of Diptera and Coleoptera, and an interaction between number of Hymenoptera and broadleaf forb cover (Table 2). The most supported cover model included total vegetation cover and visual obstruction from $0 \mathrm{~cm}$ to $45.7 \mathrm{~cm}$ in height (Table 3). The cover model explained more variation than the food model, but a combination of covariates included in food and cover models provided the best overall model for the 2011-2012 data (Table 4). There was moderate uncertainty between the top 2 combined models so we model averaged parameters to derive estimates.

We evaluated 40 combined food and cover models for the 2011-2013 data set. The vegetation variables found to be influential on selection of brood-rearing sites in 2011-2012 were also included in the most supported models from 2011 to 2013 (Table 5). Due to 
TABLE 3. Model structure, number of parameters (K), log likelihood (LL), Akaike's information criterion for small sample sizes $\left(\mathrm{AIC}_{c}\right)$, difference in $\mathrm{AIC}_{c}\left(\Delta \mathrm{AIC}_{c}\right)$, Akaike weight $\left(w_{i}\right)$, and $\mathrm{McF}$ adden's pseudo $\mathrm{R}^{2}\left(\rho^{2}\right)$ for cover hypotheses explaining Greater Sage-Grouse selection of brood-rearing microsites in Carbon County, Wyoming, USA, from 2011 to 2012.

\begin{tabular}{|c|c|c|c|c|c|c|}
\hline Modela $^{\mathrm{a}}$ & $\mathrm{K}$ & LL & $\mathrm{AIC}_{c}$ & $\Delta \mathrm{AIC}_{c}$ & $w_{i}$ & $\rho^{2}$ \\
\hline PT ${ }^{\mathrm{b}}$ SectAB + TotCover + TotCover $^{2}$ & 4 & -157.974 & 324.088 & 0.000 & 0.368 & 0.092 \\
\hline PT_SectAB & 2 & -160.868 & 325.777 & 1.689 & 0.158 & 0.075 \\
\hline PT_SectAB + Bunch & 3 & -160.183 & 326.450 & 2.362 & 0.113 & 0.079 \\
\hline PT_SectAB + Rhizo & 3 & -160.724 & 327.532 & 3.444 & 0.066 & 0.076 \\
\hline PT_SectAB + TotSage & 3 & -160.767 & 327.617 & 3.528 & 0.063 & 0.076 \\
\hline PT_SectAB + TotGrass & 3 & -160.793 & 327.670 & 3.581 & 0.061 & 0.075 \\
\hline PT_SectAB + Density & 3 & -160.841 & 327.766 & 3.677 & 0.059 & 0.075 \\
\hline PT_SectAB + TotSage + Bunch & 4 & -160.081 & 328.301 & 4.213 & 0.045 & 0.080 \\
\hline PT_SectAB + TotSage + Rhizo & 4 & -160.473 & 329.085 & 4.997 & 0.030 & 0.077 \\
\hline PT_SectAB + TotGrass + TotSage & 4 & -160.748 & 329.636 & 5.547 & 0.023 & 0.076 \\
\hline Glōbal & 9 & -156.301 & 331.243 & 7.155 & 0.010 & 0.101 \\
\hline TotCover + TotCover $^{2}+$ Bunch & 4 & -163.735 & 335.609 & 11.521 & 0.001 & 0.059 \\
\hline TotCover + TotCover $^{2}+$ TotSage & 4 & -163.812 & 335.763 & 11.675 & 0.001 & 0.058 \\
\hline TotCover + TotCover $^{2}$ & 3 & -165.885 & 337.853 & 13.765 & 0.000 & 0.046 \\
\hline TotCover + TotCover $^{2}+$ GrassHt & 4 & -165.561 & 339.262 & 15.174 & 0.000 & 0.048 \\
\hline TotCover + TotCover ${ }^{2}+$ Rhizo & 4 & -165.632 & 339.403 & 15.315 & 0.000 & 0.048 \\
\hline TotSage + GrassHt & 3 & -167.806 & 341.697 & 17.608 & 0.000 & 0.035 \\
\hline Rhizo + TotSage & 3 & -167.901 & 341.886 & 17.798 & 0.000 & 0.035 \\
\hline GrassHt & 2 & -170.666 & 345.373 & 21.284 & 0.000 & 0.019 \\
\hline Rhizo & 2 & -171.331 & 346.703 & 22.615 & 0.000 & 0.015 \\
\hline TotGrass + GrassHt & 3 & -170.661 & 347.405 & 23.317 & 0.000 & 0.019 \\
\hline TotSage & 2 & -171.753 & 347.547 & 23.459 & 0.000 & 0.012 \\
\hline Bunch & 2 & -172.509 & 349.060 & 24.971 & 0.000 & 0.008 \\
\hline Null & 1 & -173.915 & 349.845 & 25.756 & 0.000 & 0.000 \\
\hline TotGrass & 2 & -173.049 & 350.140 & 26.052 & 0.000 & 0.005 \\
\hline Cheatgrass & 2 & -173.307 & 350.656 & 26.567 & 0.000 & 0.003 \\
\hline Density & 2 & -173.479 & 350.999 & 26.910 & 0.000 & 0.003 \\
\hline
\end{tabular}

aTotCover $=$ foliar canopy cover of all vegetation, excluding litter; Sect $\mathrm{AB}=$ number of obstructed 1.27 -cm increments from $0 \mathrm{~cm}$ to $45.7 \mathrm{~cm}$ in height; Bunch $=$ foliar canopy cover of bunchgrasses: Rhizo $=$ foliar canopy cover of rhizomatous grasses; TotSage $=$ foliar canopy cover of sagebrush (Artemisia spp.), excluding A. frigida and A. pedatifida; TotGrass = foliar canopy cover of grasses; Cheatgrass = foliar canopy cover of cheatgrass (Bromus tectorum); Density = density of sagebrush; GrassHt = natural droop height of grasses; Global = fully parameterized model; Null = unparameterized model

bPT: Pseudothreshold form of the variable.

TABLE 4. Model structure, number of parameters (K), log likelihood (LL), Akaike's information criterion for small sample sizes $\left(\mathrm{AIC}_{c}\right)$, difference in $\mathrm{AIC}_{c}\left(\Delta \mathrm{AIC}_{c}\right)$, Akaike weight $\left(w_{i}\right)$, and $\mathrm{McFadden}$ 's pseudo $\mathrm{R}^{2}\left(\rho^{2}\right)$ for combined food and cover hypotheses explaining Greater Sage-Grouse selection of brood-rearing microsites in Carbon County, Wyoming, USA, from 2011 to 2012.

\begin{tabular}{|c|c|c|c|c|c|c|}
\hline Model $^{\mathrm{a}}$ & $\mathrm{K}$ & LL & $\mathrm{AIC}_{c}$ & $\Delta \mathrm{AIC}_{c}$ & $w_{i}$ & $\rho^{2}$ \\
\hline $\begin{array}{l}\text { PTb_Hym + PT_Dip + Col + PT_BroadForb + } \\
\text { PT_Hym*PT_BroadForb }+ \text { TotCover }+ \\
\text { TotCover }{ }^{2}+\text { PT_SectAB }\end{array}$ & 9 & -150.727 & 320.094 & 0.000 & 0.569 & 0.133 \\
\hline $\begin{array}{l}\text { PT_Hym + PT_Dip + Col + PT_BroadForb + } \\
\text { PT_Hym*PT_BroadForb + PT_SectAB }\end{array}$ & 7 & -153.425 & 321.245 & 1.151 & 0.320 & 0.118 \\
\hline TotCover + TotCover ${ }^{2}+$ PT_SectAB & 4 & -157.974 & 324.088 & 3.994 & 0.077 & 0.092 \\
\hline PT_SectAB & 2 & -160.868 & 325.777 & 5.683 & 0.033 & 0.075 \\
\hline $\begin{array}{l}\text { PT_Hym + PT_Dip + Col + PT_BroadForb + } \\
\text { PT_Hym*PT_BroadForb }\end{array}$ & 6 & -159.997 & 332.291 & 12.197 & 0.001 & 0.080 \\
\hline Null & 1 & -173.915 & 349.845 & 29.751 & 0.000 & 0.000 \\
\hline
\end{tabular}

a ${ }^{\mathrm{H} y m}=$ number of Hymenoptera; Dip = number of Diptera; Col = number of Coleoptera; TotCover = foliar canopy cover of all vegetation, excluding litter; $\mathrm{SectAB}=$ number of obstructed $1.27-\mathrm{cm}$ increments from $0 \mathrm{~cm}$ to $45.7 \mathrm{~cm}$ in height; BroadForb $=$ foliar canopy cover of broad-leaf forbs; Null $=$ unparameterized model.

bPT: Pseudothreshold form of the variable. 
TABLE 5. Model structure, number of parameters (K), log likelihood (LL), Akaike's information criterion for small sample sizes $\left(\mathrm{AIC}_{c}\right)$, difference in $\mathrm{AIC}_{c}\left(\Delta \mathrm{AIC}_{c}\right)$, Akaike weights $\left(w_{i}\right)$, and McFadden's pseudo $\mathrm{R}^{2}\left(\rho^{2}\right)$ for food and cover hypotheses explaining Greater Sage-Grouse selection of brood-rearing microsites in Carbon County, Wyoming, USA, from 2011 to 2013. We excluded arthropod variables from model analysis because arthropods were not sampled in 2013.

\begin{tabular}{|c|c|c|c|c|c|c|}
\hline Model $^{\mathrm{a}}$ & K & LL & $\mathrm{AIC}_{c}$ & $\Delta \mathrm{AIC}_{c}$ & $w_{i}$ & $\rho^{2}$ \\
\hline $\begin{array}{l}\text { PT b_SectAB + TotCover + TotCover }{ }^{2}+ \\
\text { PT_BroadForb }\end{array}$ & 5 & -220.644 & 451.433 & 0.000 & 0.363 & 0.118 \\
\hline PT_SectAB + TotCover + TotCover ${ }^{2}$ & 4 & -222.361 & 452.819 & 1.387 & 0.182 & 0.112 \\
\hline $\begin{array}{l}\text { PT_SectAB + TotCover }+ \text { TotCover }{ }^{2}+ \\
\text { PT_Bunch }\end{array}$ & 5 & -221.546 & 453.237 & 1.804 & 0.147 & 0.115 \\
\hline $\begin{array}{l}\text { PT_SectAB + TotCover }+ \text { TotCover }^{2}+ \\
\text { PT_TotGrass }\end{array}$ & 5 & -221.661 & 453.467 & 2.034 & 0.131 & 0.114 \\
\hline $\begin{array}{l}\text { PT_SectAB }+ \text { TotCover }+ \text { TotCover }{ }^{2}+ \\
\text { TotForb }\end{array}$ & 5 & -221.969 & 454.084 & 2.652 & 0.097 & 0.113 \\
\hline $\begin{array}{l}\text { PT_SectAB }+ \text { TotCover }+ \text { TotCover }^{2}+ \\
\text { TotSage }\end{array}$ & 5 & -222.280 & 454.705 & 3.272 & 0.071 & 0.112 \\
\hline $\begin{array}{c}\text { PT_BroadForb + TotCover + } \\
\text { TotCover }{ }^{2}+\text { PT_GrassHt }\end{array}$ & 5 & -224.631 & 459.407 & 7.974 & 0.007 & 0.102 \\
\hline Global & 11 & -219.774 & 462.197 & 10.765 & 0.002 & 0.122 \\
\hline TotCover + TotCover ${ }^{2}+$ PT_GrassHt & 4 & -228.690 & 465.477 & 14.044 & 0.000 & 0.086 \\
\hline PT_SectAB + PT_BroadForb & 3 & -231.899 & 469.856 & 18.423 & 0.000 & 0.073 \\
\hline PT_SectAB & 2 & -234.169 & 472.367 & 20.934 & 0.000 & 0.064 \\
\hline PT_SectAB + PT_Bunch & 3 & -233.288 & 472.633 & 21.200 & 0.000 & 0.068 \\
\hline PT_SectAB + PT_TotGrass & 3 & -233.316 & 472.689 & 21.257 & 0.000 & 0.068 \\
\hline PT_SectAB + TotForb & 3 & -233.433 & 472.923 & 21.490 & 0.000 & 0.067 \\
\hline PT_SectAB + Rhizo & 3 & -233.628 & 473.314 & 21.882 & 0.000 & 0.067 \\
\hline PT_SectAB + PT_CushionForb & 3 & -233.738 & 473.533 & 22.101 & 0.000 & 0.066 \\
\hline PT_SectAB + Density & 3 & -233.923 & 473.903 & 22.470 & 0.000 & 0.065 \\
\hline PT_SectAB + TotSage & 3 & -234.045 & 474.148 & 22.716 & 0.000 & 0.065 \\
\hline PT_SectAB + TotSage + PT_Bunch & 4 & -233.244 & 474.584 & 23.152 & 0.000 & 0.068 \\
\hline PT_SectAB + PT_TotGrass $+\overline{+}$ TotSage & 4 & -233.315 & 474.726 & 23.294 & 0.000 & 0.068 \\
\hline PT_SectAB + TotSage + Rhizo & 4 & -233.620 & 475.336 & 23.904 & 0.000 & 0.067 \\
\hline TotCover + TotCover ${ }^{2}$ & 3 & -234.699 & 475.457 & 24.024 & 0.000 & 0.062 \\
\hline $\begin{array}{l}\text { PT_BroadForb + PT_TotGrass }+ \\
\text { TotSage }\end{array}$ & 4 & -236.282 & 480.661 & 29.229 & 0.000 & 0.056 \\
\hline PT_BroadForb & 2 & -238.550 & 481.129 & 29.696 & 0.000 & 0.047 \\
\hline PT_BroadForb + PT_CushionForb & 3 & -238.150 & 482.357 & 30.924 & 0.000 & 0.048 \\
\hline $\begin{array}{l}\text { PT_BroadForb + PT_TotGrass + } \\
\text { PT_GrassHt }\end{array}$ & 4 & -237.139 & 482.374 & 30.942 & 0.000 & 0.052 \\
\hline TotSage + PT_GrassHt & 3 & -241.590 & 489.239 & 37.806 & 0.000 & 0.035 \\
\hline PT_GrassHt ${ }^{-}$ & 2 & -242.774 & 489.577 & 38.144 & 0.000 & 0.030 \\
\hline TotForb + PT_TotGrass + PT_GrassHt & 4 & -240.772 & 489.641 & 38.208 & 0.000 & 0.038 \\
\hline PT_TotGrass + PT_GrassHt & 3 & -242.036 & 490.129 & 38.696 & 0.000 & 0.033 \\
\hline Rhizo + TotSage & 3 & -244.274 & 494.607 & 43.174 & 0.000 & 0.024 \\
\hline Rhizo & 2 & -246.227 & 496.483 & 45.050 & 0.000 & 0.016 \\
\hline PT_TotGrass & 2 & -246.268 & 496.566 & 45.133 & 0.000 & 0.016 \\
\hline TotForb & 2 & -246.328 & 496.685 & 45.253 & 0.000 & 0.016 \\
\hline PT_CushionForb & 2 & -247.428 & 498.885 & 47.452 & 0.000 & 0.011 \\
\hline PT_Bunch & 2 & -248.619 & 501.266 & 49.834 & 0.000 & 0.007 \\
\hline Density & 2 & -248.780 & 501.588 & 50.156 & 0.000 & 0.006 \\
\hline Null & 1 & -250.278 & 502.567 & 51.134 & 0.000 & 0.000 \\
\hline TotSage & 2 & -249.371 & 502.772 & 51.339 & 0.000 & 0.004 \\
\hline Cheatgrass & 2 & -249.895 & 503.819 & 52.386 & 0.000 & 0.002 \\
\hline
\end{tabular}

a TotCover = foliar canopy cover of all vegetation, excluding litter; SectAB = number of obstructed $1.27-\mathrm{cm}$ increments from $0 \mathrm{~cm}$ to $45.7 \mathrm{~cm}$ in height; BroadForb $=$ foliar canopy cover of broad-leaf forbs; CushionForb = foliar canopy cover of cushion/mat-forming forbs; Bunch = foliar canopy cover of bunchgrasses; Rhizo $=$ foliar canopy cover of rhizomatous grasses; TotGrass $=$ foliar canopy cover of grasses; TotForb $=$ foliar canopy cover of all forbs; TotSage $=$ foliar canopy cover of sagebrush (Artemisia spp.) species, excluding A frigida and A pedatifida: Density $=$ density of sagebrush: GrassHt $=$ natural droop height of grasses; Cheatgrass = foliar canopy cover of cheatgrass (Bromus tectorum); Global = fully parameterized model; Null = unparameterized model. bPT: Pseudothreshold form of the variable. 
TABLE 6. Model-averaged parameter estimates, standard errors (SE), and 95\% confidence intervals (L95\% and U95\%) explaining Greater Sage-Grouse selection of brood-rearing microsites in Carbon County, Wyoming, USA, from 2011 to 2012 and 2011 to 2013.

\begin{tabular}{|c|c|c|c|c|c|}
\hline Years & Parameter $^{\mathrm{a}}$ & Estimate & $\mathrm{SE}$ & $\mathrm{L} 95 \%$ & U95\% \\
\hline \multirow[t]{8}{*}{$2011-2012$} & PTb_SectAB & $1.271^{* * \mathrm{c}}$ & 0.433 & 0.422 & 2.121 \\
\hline & TotCover & $0.192 * *$ & 0.090 & 0.015 & 0.369 \\
\hline & TotCover ${ }^{2}$ & $-0.0015^{* *}$ & 0.0007 & -0.0028 & -0.0001 \\
\hline & PT_Dip & $0.436 * *$ & 0.216 & 0.014 & 0.859 \\
\hline & PT_Hym & $0.697 * *$ & 0.332 & 0.047 & 1.348 \\
\hline & PT_BroadForb & $0.761 *$ & 0.414 & -0.051 & 1.574 \\
\hline & PT_Hym*PT_BroadForb & $-0.294^{*}$ & 0.158 & -0.604 & 0.016 \\
\hline & Col̄ & $-0.206^{* *}$ & 0.097 & -0.395 & -0.016 \\
\hline \multirow[t]{5}{*}{ 2011-2013 } & PT_SectAB & $1.004 * *$ & 0.306 & 0.405 & 1.604 \\
\hline & TotCover & $0.205^{* *} *$ & 0.067 & 0.074 & 0.336 \\
\hline & TotCover ${ }^{2}$ & $-0.0014^{* *}$ & 0.0005 & -0.0024 & -0.0003 \\
\hline & PT_BroadForb & $0.333 *$ & 0.183 & -0.025 & 0.691 \\
\hline & PT_Bunch & -0.431 & 0.337 & -1.092 & 0.230 \\
\hline
\end{tabular}

$\overline{{ }^{a} H y m}=$ number of Hymenoptera $\left(\right.$ no. $\left./ 6 \mathrm{~m}^{2}\right)$; Dip = number of Diptera $\left(\right.$ no. $\left./ 6 \mathrm{~m}^{2}\right)$; Col = number of Coleoptera $\left(\right.$ no. $\left./ 6 \mathrm{~m}^{2}\right)$; TotCover $=$ foliar canopy cover $(\%)$ of all vegetation, excluding litter; SectAB = number of obstructed $1.27-\mathrm{cm}$ increments from $0 \mathrm{~cm}$ to $45.7 \mathrm{~cm}$ in height; BroadForb = foliar canopy cover $(\%)$ of broad-leaf forbs; Bunch = foliar canopy cover $(\%)$ of bunchgrasses.

bPT: Pseudothreshold form of the variable.

$\mathrm{c} * *=95 \%$ significance; $*=90 \%$ significance.

model uncertainty, we model averaged the top 3 models to derive separate parameter estimates for the 2011-2013 data set.

From 2011 to 2012 , number of Diptera had a significant $(P<0.05)$ positive pseudothreshold association with brood-rearing site selection, whereas number of Coleoptera had a significant negative linear association (Table 6). The interaction between number of Hymenoptera and broad-leaf forb cover was insignificant at the $95 \%$ confidence level, but significant at the $90 \%$ confidence level. The relative probability of a site being selected increased logistically with increasing number of Hymenoptera, if there was low cover $(<20 \%)$ of broad-leaf forbs. However, relative probability of selection decreased with increasing number of Hymenoptera when there were was $>20 \%$ broad-leaf forb cover at the site (Fig. 2).

The pseudothreshold form of visual obstruction from $0 \mathrm{~cm}$ to $45.7 \mathrm{~cm}$ in height and the quadratic form of total vegetation cover had significant $(P<0.05)$ relationships with brood-rearing site selection for both data sets (Table 6). Relative probability of selection increased logistically with increasing visual obstruction but peaked at approximately $75 \%$ vegetation cover (Fig. 3). Broad-leaf forb cover had a positive pseudothreshold association with brood-rearing site selection in 20112013 , but the relationship was only significant at the $90 \%$ confidence level.

McFadden's $\rho^{2}$ values for top models suggested that our models performed marginally well, but not excellently. Squared semipartial correlations of variables in the final models indicated that number of Coleoptera explained the least variation $(1.50 \%)$ in brood-rearing site selection from 2011 to 2012, whereas visual obstruction from $0 \mathrm{~cm}$ to $45.7 \mathrm{~cm}$ in height explained the most variation $(2.62 \%)$. Similarly, visual obstruction explained the most variation (4.73\%) in selection from 2011 to 2013 and bunchgrass cover explained the least variation $(0.33 \%)$. Cross validation procedures correctly classified $46.6 \%$ of the broodrearing sites in the 2011-2012 data set and $43.8 \%$ of the brood-rearing sites for the 20112013 data set. When compared individually with the $50-\mathrm{m}, 250-\mathrm{m}$, and $500-\mathrm{m}$ pairedrandom sites, the brood-rearing site was correctly classified, respectively, in $61.6 \%, 76.7 \%$, and $71.2 \%$ of the choice sets using the 20112012 model, and correctly classified in $66.7 \%$, $65.7 \%$, and $82.9 \%$ of the choice sets using the 2011-2013 model.

\section{Discussion}

Sage-grouse rearing broods often select diurnal sites with concealing cover to prevent predation and exposure-related chick mortality (Wallestad 1971, Sveum et al. 1998, Aldridge and Brigham 2002, Thompson et al. 2006, Kaczor et al. 2011, Kirol et al. 2012). The strong influence of visual obstruction from $0 \mathrm{~cm}$ to $45.7 \mathrm{~cm}$ in height on brood-rearing site selection in our study confirms that concealing 

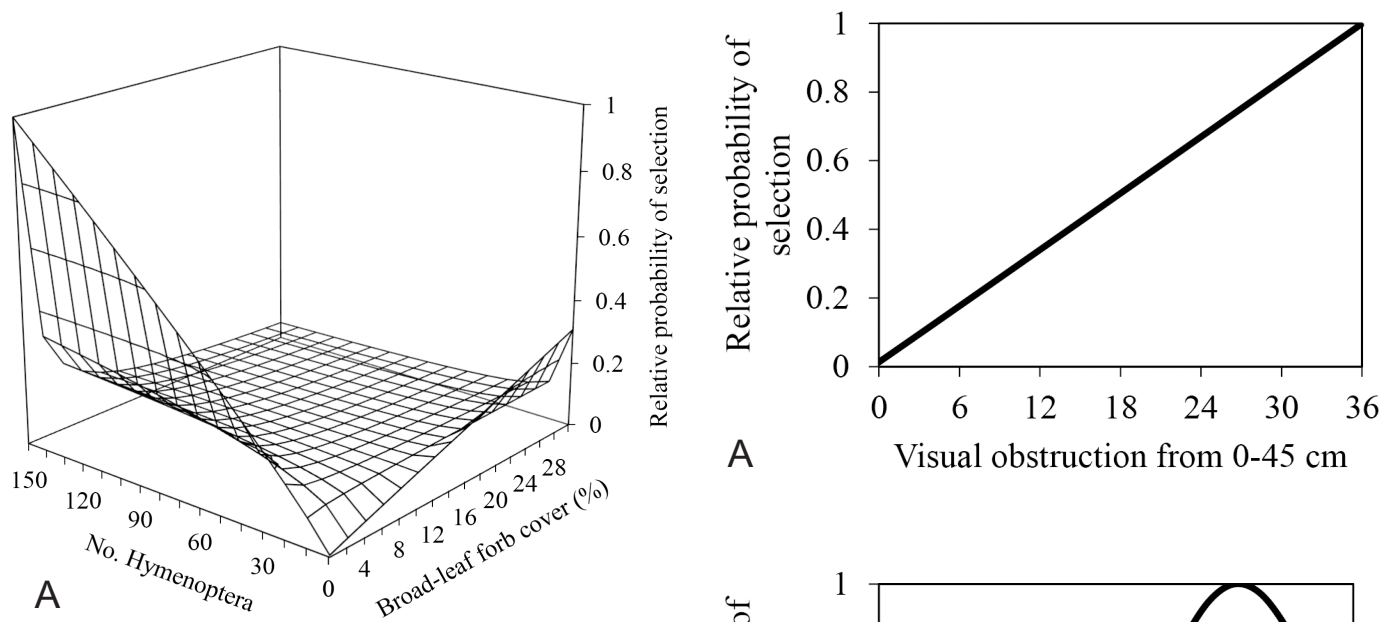

A

Visual obstruction from $0-45 \mathrm{~cm}$

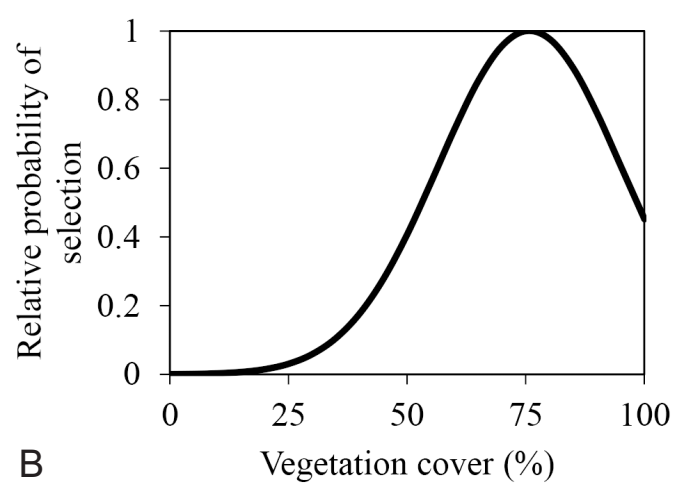

B
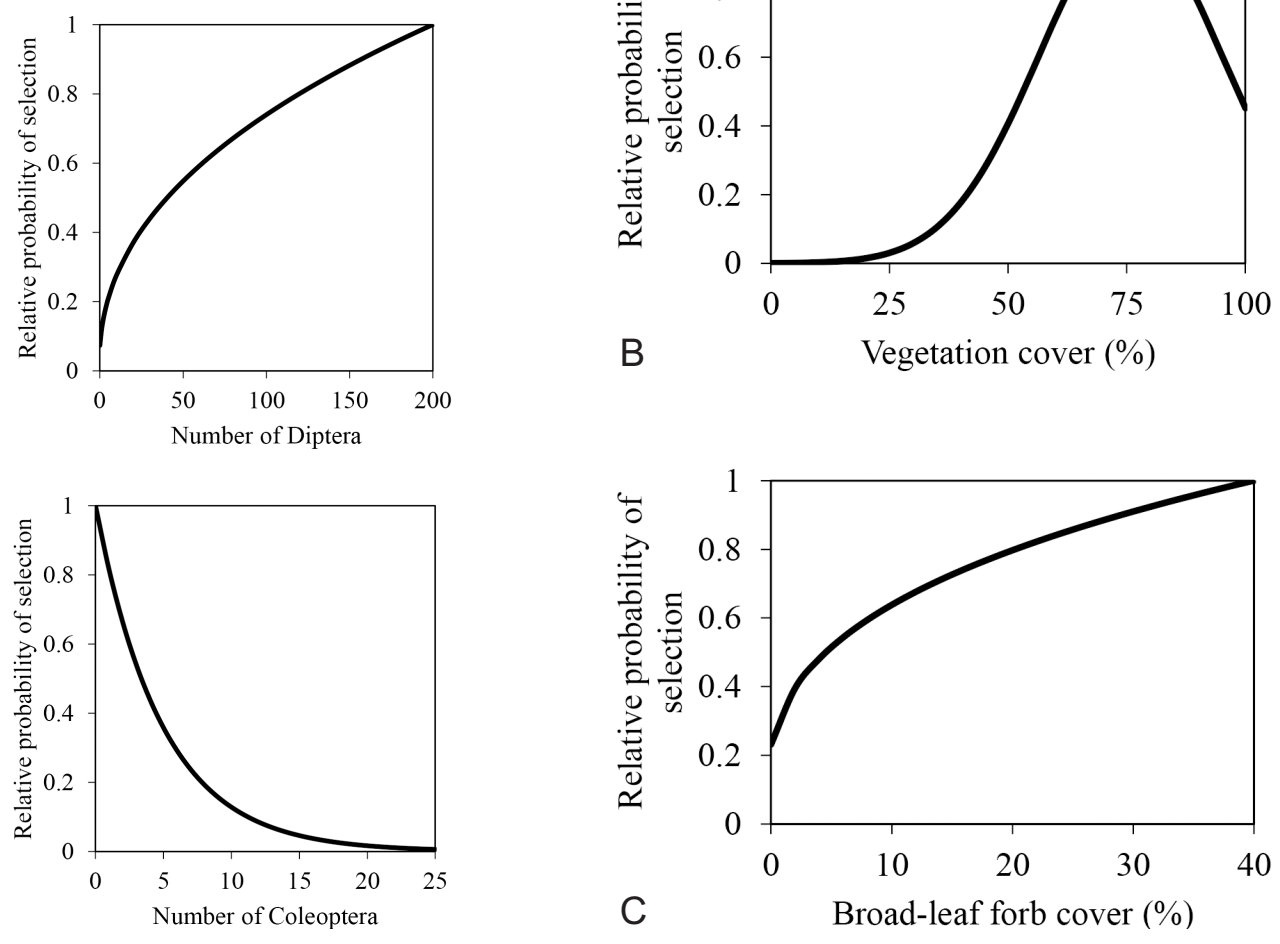

Fig. 2. Influence of (A) the interaction between number of Hymenoptera (no. $\left./ 6 \mathrm{~m}^{2}\right)$ and foliar canopy cover $(\%)$ of broad-leaf forbs; (B) number of Diptera $\left(\right.$ no. $\left./ 6 \mathrm{~m}^{2}\right)$; and $(\mathrm{C})$ number of Coleoptera (no./6 $\left.\mathrm{m}^{2}\right)$ on the relative probability of Greater Sage-Grouse selecting brood-rearing microsites in Carbon County, Wyoming, USA, from 2011 to 2012 These graphs demonstrate the relative change in selection probability, rescaled from 0 to 1 , not the absolute probability of a site being selected. We removed confidence intervals from figures because confidence intervals are conditional upon the choice set that is evaluated. We evaluated a hypothetical set of 256 available choices for graph A, and 25 choices for graphs B and C, each with incrementally increasing values of the variable of interest.

Fig. 3. Influence of (A) visual obstruction (no. of 1.27$\mathrm{cm}$ increments with $>50 \%$ obstruction) from 0 to $45 \mathrm{~cm}$ in height, (B) foliar canopy cover (\%) of all vegetation species, and (C) foliar canopy cover (\%) of broad-leaf forbs on Greater Sage-Grouse selection of brood-rearing sites in Carbon County, Wyoming, USA, from 2011 to 2013. These graphs demonstrate the relative change in selection probability, rescaled from 0 to 1 , not the absolute probability of a site being selected. We removed confidence intervals from figures because confidence intervals are conditional upon the choice set that is evaluated. We evaluated a hypothetical set of 25 available choices, each with incrementally increasing values of the variable of interest. 
cover is a high priority. Our result that relative probability of selection decreased with increasing vegetation cover $>75 \%$ should not discount the importance of visual obstruction on selection of brood-rearing sites because this metric is not directly associated with concealing cover. Wambolt et al. (2002) suggested that herbaceous vegetation can become "too thick" for good brood cover. Further, Klebenow (1985) found that brood-rearing sage-grouse selected grazed meadows with average vegetation heights of 7-15 cm, whereas available vegetation averaged $10-25 \mathrm{~cm}$. Thus, a mosaic of varying vegetation cover and heights that provides both foraging and escape areas might be most beneficial for broods (Klebenow 1985). Brood-rearing sage-grouse typically use cover dominated by sagebrush in late spring/early summer and then transition to mesic sites with more herbaceous cover (Connelly et al. 2011). While total vegetation cover was important for selection of brood-rearing sites, we found no influence of species-specific cover types in our analysis. This could be a result of the diversity of vegetation types used by brood-rearing sage-grouse on our study area or a dilution of effects by combining early and late brood-rearing periods.

It is well-known that arthropods are important to sage-grouse broods (e.g., Drut et al. 1994, Fischer et al. 1996, Connelly et al. 2000, Dahlgren et al. 2010) because chicks require arthropods for proper development and survival during the first few weeks post hatch (Johnson and Boyce 1990). The inclusion of arthropod covariates in our final model suggests that arthropod abundance influences brood-rearing site selection on our study site. However, not all arthropod orders included in our final model had positive influences on selection. Coleoptera were some of the most prevalent arthropods consumed by sage-grouse chicks in Idaho, Montana, and Oregon (Klebenow and Gray 1968, Peterson 1970, Drut et al. 1994), but number of Coleoptera had a significant negative correlation with selection in our study. We caution the interpretation of this finding, given that Coleoptera explained the least variation in selection of brood-rearing sites compared to other variables in the most supported model. This relationship might not be a result of brood-rearing sage-grouse actively avoiding Coleoptera, rather sage-grouse using vegetation communities that may be less attractive to some Coleoptera. Darkling beetles (Tenebrionidae), one of the most common beetles in western North America (Crawford 1981), and a food source for sage-grouse chicks (Klebenow and Gray 1968, Drut et al. 1994), are largely associated with shrubdominated habitats (Rickard and Haverfield 1965, Parmenter et al. 1989, McIntyre 1997, Stapp 1997). Brood-rearing females in our study often selected sites in mesic areas with high herbaceous cover that may not have been attractive to darkling beetles but harbored large densities of other arthropods (Knops et al. 1999, Wenninger and Inouye 2008). Similarly, harvester ants (Pogonomyrmex spp.), one the most common species of Hymenoptera on our study area, are associated with sandy soils in arid environments (Kirkham and Fisser 1972), whereas broad-leaf forbs on our study site were typically associated with mesic sites. The increase in the relative probability of sagegrouse selecting sites with high numbers of Hymenoptera but low cover of broad-leaf forbs, or high broad-leaf forb cover and low number of Hymenoptera, could be a result of harvester ants not being as abundant in mesic sites. Alternatively, the interaction could be influenced by changing foraging habits, as chick diets shift from Hymenoptera (mostly ants) and beetles early in the brood-rearing season to forbs late in the season (Klebenow and Gray 1968, Peterson 1970).

Forbs are an important food source for sage-grouse chicks, especially late in the brood-rearing period (Klebenow and Gray 1968, Peterson 1970, Drut et al. 1994, Sveum et al. 1998). Though insignificant, the trends we observed suggest that broad-leaf forb cover was more influential on brood-rearing site selection than cushion forb cover. Most forbs consumed by chicks in Idaho, Montana, and Oregon were broad-leaf forbs (Klebenow and Gray 1968, Peterson 1970, Drut et al. 1994) with high crude protein content (Barnett and Crawford 1994). Sage-grouse rearing broods on our study area may have selected sites with broadleaf forbs for their increased nutritional value. Some species of phlox are also consumed by sage-grouse chicks (Klebenow and Gray 1968, Drut et al. 1994) and might improve survival of chicks (Gregg and Crawford 2009). However, phlox and other cushion forbs such as goldenweed were primarily located in dry, rocky vegetation communities on our study 
area (e.g., Gucker 2006), whereas broad-leaf forbs were often associated with mesic communities preferred by brood-rearing sage-grouse.

Similar to other studies concerning sagegrouse brood-rearing habitat, our results demonstrate that food and cover attributes are both important components of sage-grouse diurnal selection of brood-rearing sites. Most variables in our top models had pseudothreshold or quadratic forms, which suggests there is an optimum level of food and cover attributes, and a combination of these attributes is likely preferred. Sage-grouse rearing broods acquired food and cover within a diverse array of vegetation types across ecoregions on our study area but consistently selected sites within mesic communities, especially late in the broodrearing season. High moisture in mesic communities produces visual cover from grasses and shrubs, as well as high abundance and diversity of food resources from forbs and arthropods (Jamison et al. 2002, Wenninger and Inouye 2008). The diversity of vegetation types selected within mesic communities and the increased predictive ability of our model at scales $>50 \mathrm{~m}$ from the used site suggest that community-level food and cover characteristics may be more influential on selection of brood-rearing sites than individual attributes within the community (e.g., Harju et al. 2013). Available sites within $50 \mathrm{~m}$ of the used site were often in the same vegetation community, which could explain why our model did not differentiate these sites as well as it differentiated sites located $250 \mathrm{~m}$ or $500 \mathrm{~m}$ from the used site. Thus, our results could be used to identify vegetation communities with high relative probabilities of use by sage-grouse rearing broods, which will help guide management decisions and provide reference conditions for future research that evaluates the effects of wind energy development on sage-grouse.

\section{ACKNOWLEDGMENTS}

The research associated with this publication resulted from research funded, in part, by U.S. Forest Service Rocky Mountain Research Station, Wyoming Game and Fish Department, Power Company of Wyoming LLC, Bureau of Land Management, U.S. Department of Energy National Renewable Energy Laboratory, Western Association of Fish and Wildlife Agencies, National Fish and Wildlife
Foundation, and SWCA Environmental Consultants. The National Wind Coordinating Collaborative and American Wind Wildlife Institute helped to acquire funds for our research program focused on sage-grouse ecology and wind energy development. A. Fremgen and many technicians assisted with sage-grouse tagging, tracking, and associated fieldwork, and S. Baggett assisted with development and interpretation of statistical analyses. M. Morrison and 2 anonymous reviewers provided helpful comments that improved the manuscript. We particularly thank G. Miller, Vice President of Land and Environmental Affairs, Power Company of Wyoming LLC, and the Overland Trail Cattle Company LLC, for their support of the project and assistance with field activities.

\section{Literature Cited}

AKaIKe, H. 1973. Information theory as an extension of the maximum likelihood principle. Pages 267-281 in B.N. Petrov and F. Csaki, editors, Second International Symposium on Information Theory. Akadémiai Kiadó, Budapest, Hungary.

Aldridge, C.L. 2000. Reproduction and habitat use by sage grouse (Centrocercus urophasianus) in a northern fringe population. Master's thesis, University of Regina, Regina, Saskatchewan, Canada.

Aldridge, C.L., AND R.M. Brigham. 2002. Sage-grouse nesting and brood habitat use in southern Canada. Journal of Wildlife Management 66:433-444.

Barnett, J.K., and J.A. Crawford. 1994. Pre-laying nutrition of sage grouse hens in Oregon. Journal of Range Management 47:114-118.

Beck, J.L., K.P. Reese, J.W. Connelly, and M.B. Lucia. 2006. Movements and survival of juvenile Greater Sage-Grouse in southeastern Idaho. Wildlife Society Bulletin 34:1070-1078.

Benkobi, L., D.W. Uresk, G. Schenbeck, and R.M. KING. 2000. Protocol for monitoring standing crop in grasslands using visual obstruction. Journal of Range Management 53:627-633.

Booth, D.T., S.E. Cox, T.W. Meikle, and C. Fitzgerald. 2006. The accuracy of ground-cover measurements. Rangeland Ecology and Management 59:179-188.

Boyce, M.S., P.R. Vernier, S.E. Nielsen, and F.K. SCHMiEgELOW. 2002. Evaluating resource selection functions. Ecological Modelling 157:281-300.

Braun, C.E. 1998. Sage grouse declines in western North America: what are the problems? Proceedings of the Western Association of State Fish and Wildlife Agencies 78:139-156.

Burnham, K.P., AND D.R. ANDERSON. 2002. Model selection and multimodel inference: a practical informationtheoretic approach. 2nd edition. Springer-Verlag, New York, NY.

Cagney, J., E. Bainter, B. Budd, T. Christiansen, V. Herren, M. Holloran, B. Rashford, M. Smith, AND J. WiLLIAMS. 2010. Grazing influence, objective 
development, and management in Wyoming's Greater Sage-Grouse habitat. University of Wyoming Cooperative Extension Service, Laramie, WY.

Chapman, S.S., S.A. Bryce, J.M. Omernik, D.G. Despain, J. SumBerge, and M. Conrad. 2004. Ecoregions of Wyoming [color poster with map, descriptive text, summary tables, and photographs]. U.S. Geological Survey, Reston, VA.

COHEN, J., AND P. COHEN. 1975. Applied multiple regression and correlation analysis for the behavioral sciences. Lawrence Erlbaum Associates, Hillsdale, NJ.

Connelly, J.W., ANd C.E. Braun. 1997. Long-term changes in sage grouse Centrocercus urophasianus populations in western North America. Wildlife Biology 3: 229-234.

Connelly, J.W., S.T. Knick, M.A. Schroeder, And S.J. StIVER. 2004. Conservation assessment of Greater Sage-Grouse and sagebrush habitats. Western Association of Fish and Wildlife Agencies, Cheyenne, WY.

Connelly, J.W., K.P. ReEse, AND M.A. SChroeder. 2003. Monitoring of Greater Sage-Grouse habitats and populations. University of Idaho, College of Natural Resources Experiment Station Bulletin 80, Moscow, ID.

Connelly, J.W., E.T. Rinkes, and C.E. Braun. 2011. Characteristics of Greater Sage-Grouse habitats: a landscape species at micro- and macroscales. Pages 69-83 in S.T. Knick and J.W. Connelly, editors, Greater Sage-Grouse: ecology and conservation of a landscape species and its habitats. University of California Press, Berkeley, CA.

Connelly, J.W., M.A. Schroeder, A.R. Sands, and C.E. BRAUN. 2000. Guidelines to manage sage grouse populations and their habitats. Wildlife Society Bulletin 28:967-985.

Cottam, G., and J.T. CurTis. 1956. The use of distance measures in phytosociological sampling. Ecology 37 : $451-460$

Crawford, C.S. 1981. Biology of desert invertebrates. Springer-Verlag, Berlin, Germany. dx.doi.org/10.1007/ 978-3-642-85794-2

DAHLGREN, D.K. 2009. Greater Sage-Grouse ecology, chick survival, and population dynamics, Parker Mountain, Utah. Doctoral dissertation, Utah State University, Logan, UT

Dahlgren, D.K., T.A. Messmer, E.T. Thacker, and M.R. GUTTERY. 2010. Evaluation of brood detection techniques: recommendations for estimating Greater Sage-Grouse productivity. Western North American Naturalist 70:233-237.

Daubenmire, R. 1959. A canopy-coverage method of vegetational analysis. Northwest Science 33:43-64.

Drut, M.S., W.H. Pyle, and J.A. Crawford. 1994. Diets and food selection of sage grouse chicks in Oregon. Journal of Range Management 47:90-93.

Fischer, R.A., K.P. ReEse, And J.W. Connelly. 1996. An investigation on fire effects within xeric sage grouse brood habitat. Journal of Range Management 49: 194-198.

Franklin, A.B., D.R. Anderson, R.T. Gutiérrez, and K.P. Burnham. 2000. Climate, habitat quality, and fitness in Northern Spotted Owl populations in northwestern California. Ecological Monographs 70: 539-590.

Garton, E.O., J.W. Connelly, J.S. Horne, C.A. Hagen, A. Moser, And M.A. Schroeder. 2011. Greater SageGrouse population dynamics and probability of persistence. Pages 293-381 in S.T. Knick and J.W.
Connelly, editors, Greater Sage-Grouse: ecology and conservation of a landscape species and its habitats. University of California Press, Berkeley, CA.

Giesen, K.M., T.J. Schoenberg, and C.E. Braun. 1982. Methods for trapping sage grouse in Colorado. Wildlife Society Bulletin 10:224-231.

GiraRD, G.L. 1939. Notes on life history of the shoveler. Transactions of the North American Wildlife Conference 4:364-371.

GregG, M.A. 2006. Greater Sage-Grouse reproductive ecology: linkages among habitat resources, maternal nutrition, and chick survival. Doctoral dissertation, Oregon State University, Corvallis, OR.

Gregg, M.A., and J.A. Crawford. 2009. Survival of Greater Sage-Grouse chicks and broods in the northern Great Basin. Journal of Wildlife Management 73: 904-913.

Gucker, C.L. 2006. Phlox hoodii. In: Fire Effects Information System [online]. U.S. Department of Agriculture, Forest Service, Rocky Mountain Research Station, Fire Sciences Laboratory [Producer]. http:// www.fs.fed.us/database/feis/

Hagen, C.A., J.W. Connelly, and M.A. Schroeder. 2007. A meta-analysis of Greater Sage-Grouse (Centrocercus urophasianus) nesting and brood-rearing habitats. Wildlife Biology 13:42-50.

HANLEY, T.A. 1978. A comparison of the line-interception and quadrat estimation methods of determining shrub canopy coverage. Journal of Range Management 31:60-62.

Hannon, S.J., AND K. Martin. 2006. Ecology of juvenile grouse during the transition to adulthood. Journal of Zoology 269:422-433.

Harju, S.M., C.V. Olson, L. Foy-Martin, S.L. Webb, M.R. Dzialak, J.B. Winstead, and L.D. Hayden-Wing. 2013. Occurrence and success of Greater SageGrouse broods in relation to insect-vegetation community gradients. Human-Wildlife Interactions 7: 214-229.

HiLL, D.A. 1985. The feeding ecology and survival of pheasant chicks on arable farmland. Journal of Applied Ecology 22:645-654.

Jamison, B.E., R.J. Robel, J.S. Pontius, and R.D. AppleGATE. 2002. Invertebrate biomass: associations with Lesser Prairie-Chicken habitat use and sand sagebrush density in southwestern Kansas. Wildlife Society Bulletin 30:517-526.

Johnson, G.D., AND M.S. BoyCE. 1990. Feeding trials with insects in the diet of sage grouse chicks. Journal of Wildlife Management 54:89-91.

Kaczor, N.W., K.M. Herman-Brunson, K.C. Jensen, M.A. Rumble, R.W. Klaver, and C.C. Swanson. 2011. Resource selection during brood-rearing by Greater Sage-Grouse. Pages 169-177 in B.K. Sandercock, K. Martin and G. Segelbacher, editors, Ecology, conservation, and management of grouse. University of California Press, Berkeley, CA.

Kirkham, D.R., AND H.G. Fisser. 1972. Rangeland relations and harvester ants in northcentral Wyoming. Journal of Range Management 25:55-60.

Kirol, C.P., J.L. Beck, J.B. Dinkins, and M.R. Conover. 2012. Microhabitat selection for nesting and broodrearing by the Greater Sage-Grouse in xeric big sagebrush. Condor 114:75-89.

KLebenow, D.A. 1969. Sage grouse nesting and brood habitat in Idaho. Journal of Wildlife Management 33:649-662. 
Klebenow, D.A. 1985. Habitat management for sage grouse in Nevada. World Pheasant Association Journal 10:34-46.

Klebenow, D.A., and G.M. Gray. 1968. Food habits of juvenile sage grouse. Journal of Range Management 21:80-83.

KLOTT, J.H., AND F.G. LindzEy. 1990. Brood habitats of sympatric sage grouse and Columbian Sharp-tailed Grouse in Wyoming. Journal of Wildlife Management 54:84-88.

Knops, J.M.H., D. Tilman, N.M. Haddad, S. NaEem, C.E. Mitchell, J. Haarstad, M.E. Ritchie, K.M. Howe, P.B. Reich, E. Siemann, and J. Groth. 1999. Effects of plant species richness on invasion dynamics, disease outbreaks, insect abundance and diversity. Ecology Letters 2:286-293.

Leblond, M., C. Dussault, and J. Ouellet. 2010. What drives fine-scale movements of large herbivores? A case study using moose. Ecography 33:1102-1112.

LIMA, S.L. 1998. Nonlethal effects in the ecology of predatorprey interactions. BioScience 48:25-34.

Love, J.D., AND A.C. Christiansen. 1985. Geologic map of Wyoming: scale 1:500,000. U.S. Geological Survey.

MCFAdDEN, D. 1974. Conditional logit analysis of qualitative choice behavior. Pages 105-142 in P. Zarembka, editor, Frontiers in econometrics. Academic Press, New York, NY.

MCFAdDEN, D. 1978. Quantitative methods for analyzing travel behaviour of individuals: some recent developments. Pages 279-318 in D. Hensher and P. Stopher, editors, Behavioural Travel Modelling. Croom Helm, London, England.

McIntyre, N.E. 1997. Scale-dependent habitat selection by the darkling beetle Eleodes hispilabris (Coleoptera: Tenebrionidae). American Midland Naturalist 138: 230-235.

Parmenter, R.R., C.A. Parmenter, and C.D. Cheney. 1989. Factors influencing microhabitat partitioning among coexisting species of arid-land darkling beetles (Tenebrionidae): behavioral responses to vegetation architecture. Southwestern Naturalist 34: 319-329.

Peterson, J.G. 1970. The food habits and summer distribution of juvenile sage grouse in central Montana. Journal of Wildlife Management 34:147-155.

Pollard, J.H. 1971. On distance estimators of density in randomly distributed forests. Biometrics 27:991-1002.

Power Company of Wyoming LLC. 2009. Putting wind to work for Carbon County. [Accessed May 2014]. http://www.powercompanyofwyoming.com

Rappole, J.H., and A.R. Tipton. 1991. New harness design for attachment of radio transmitters to small passerines. Journal of Field Ornithology 62:335-337.

Rickard, W.H., and L.E. Haverfield. 1965. A pitfall trapping survey of darkling beetles in desert steppe vegetation. Ecology 46:873-875.

Robel, R.J., J.N. BriggS, A.D. DaYton, and L.C. Hulbert. 1970. Relationships between visual obstruction measurements and weight of grassland vegetation. Journal of Range Management 23:295-297.

Schroeder, M.A., C.L. Aldridge, A.D. Apa, J.R. Bohne, C.E. Braun, S.D. Bunnell, J.W. Connelly, P.A.
Deibert, S.C. Gardner, M.A. Hilliard, et al. 2004. Distribution of sage-grouse in North America. Condor 106:363-376.

STAPP, P.T. 1997. Microhabitat use and community structure of darkling beetles (Coleoptera: Tenebrionidae) in shortgrass prairie: effects of season, shrub cover, and soil type. American Midland Naturalist 137:298-311.

Sveum, C.M., J.A. Crawford, and W.D. Edge. 1998. Use and selection of brood-rearing habitat by sage grouse in south-central Washington. Great Basin Naturalist 58:344-351.

Swanson, C.C., M.A. Rumble, T.W. Grovenburg, N.W. Kaczor, R.W. Klaver, K.M. Herman-Brunson, J.A. Jenks, And K.C. Jensen. 2013. Greater Sage-Grouse winter habitat use on the eastern edge of their range. Journal of Wildlife Managment 77:486-494.

Taylor, R.L., B.L. Walker, D.E. Naugle, and L.S. Mills. 2012. Managing multiple vital rates to maximize Greater Sage-Grouse population growth. Journal of Wildlife Management 76:336-347.

Thatcher, A.P. 1959. Distribution of sagebrush as related to site differences in Albany County, Wyoming. Journal of Range Management 12:55-61.

Thompson, K.M., M.J. Holloran, S.J. Slater, J.L. Kuipers, AND S.H. ANDERSON. 2006. Early brood-rearing habitat use and productivity of Greater Sage-Grouse in Wyoming. Western North American Naturalist 66: 332-342.

Thompson, T.R. 2012. Dispersal ecology of Greater SageGrouse in northwestern Colorado: evidence from demographic and genetic methods. Doctoral dissertation, University of Idaho, Moscow, ID.

United States Fish and Wildlife Service. 2010. 12month finding for petitions to list the Greater SageGrouse (Centrocercus urophasianus) as threatened or endangered. Federal Register 75:13909-14014.

VAida, F., AND S. Blanchard. 2005. Conditional Akaike information for mixed-effects models. Biometrika 92: 351-370.

WaLlestaD, R.O. 1971. Summer movements and habitat use by sage grouse broods in central Montana. Journal of Wildlife Management 35:129-136.

Wambolt, C.L., A.J. HaRP, B.L. Welch, N. ShaW, J.W. CoNnelly, K.P. Reese, C.E. Braun, D.A. Klebenow, E.D. McArthur, J.G. Thompson, ET AL. 2002. Conservation of Greater Sage-Grouse on public lands in the western U.S.: implications of recovery and management policies. Policy Paper SG-02-02, Policy Analysis Center for Western Public Lands, Caldwell, ID. 41 pp.

Wenninger, E.J., AND R.S. INOUYE. 2008. Insect community response to plant diversity and productivity in a sagebrush-steppe ecosystem. Journal of Arid Environments 72:24-33.

Western Regional Climate Center. 2013. Western United States historical climate summaries. [Accessed Oct 2013]. http://www.wrcc.dri.edu/Climsum.html

Received 15 February 2015 Accepted 5 June 2015 